\title{
HUBUNGAN ANTARA DUKUNGAN SOSIAL TEMAN SEBAYA DENGAN STRES AKADEMIK PEMBELAJARAN DARING PADA MASA PANDEMI COVID-19
}

\author{
A An Defitri ${ }^{1 *}$, Ririn Muthia Zukhra ${ }^{2}$ Nopriadi $^{3}$ \\ ${ }^{1,2,3}$ Fakultas Keperawatan, Universitas Riau \\ Email: aandef.ade@gmail.com
}

Diterima : Oktober 2021, Diterbitkan : Desember 2021

\begin{abstract}
ABSTRAK
Pembelajaran daring mengakibatkan stres akademik. Stres akademik terjadi karena tidak tercapainya penyesuaian dan adanya kegagalan menghadapi tuntutan akademik. Stres akademik yang tidak teratasi dapat mempengaruhi pikiran, perasaan, fisik dan tingkah laku. Stres akademik dapat berkurang dengan adanya dukungan sosial teman sebaya. Penelitian ini bertujuan untuk melihat hubungan antara dukungan sosial teman sebaya dengan stres akademik pembelajaran daring. Desain penelitian menggunakan deskriptif korelasi dengan pendekatan cross sectional. Penelitian dilakukan di Fakutas Keperawatan Universitas Riau dengan sampel 213 responden menggunakan proportionate stratified random sampling. Alat ukur yang digunakan berupa kuesioner stres akademik dan dukungan sosial yang dimodifikasi oleh peneliti dengan nilai rentang validitas yaitu $0,458-0,802$ dan $0,461-0,574$. Analisis yang digunakan adalah analisis univariat dan analisis bivariat. Hasil penelitian didapatkan mayoritas responden yaitu berjenis kelamin perempuan yaitu 200 (93,3\%), berusia 20 tahun adalah $77(36,2 \%)$ dan dari angkatan A 2020 adalah $75(35,2 \%)$. Mayoritas responden mendapat dukungan sosial teman sebaya tinggi mengalami stres akademik daring berat sebanyak 35 (28,7\%) dan stres akademik sedang sebanyak $87(71,3 \%)$. Hasil uji statistik didapatkan p value $=0,020<\alpha(0,05)$ artinya Ho ditolak. Simpulan penelitian ini yaitu ada hubungan antara dukungan sosial teman sebaya dengan stres akademik pembelajaran daring pada masa pandemi COVID-19.
\end{abstract}

Kata Kunci: dukungan sosial teman sebaya, pembelajaran daring, stres akademik

\begin{abstract}
Online learning causes academic stress. Academic stress occurs due to not achieving adjustments and failure to face academic demands. Unresolved academic stress can affect thoughts, feelings, physical and behavior. Academic stress can be reduced by the presence of peer social support. This study was aimed to examine the relationship between peer social support and the academic stress of online learning. This study was aimed to examine the relationship between peer social support and the academic stress of online learning. The study used Correlation descriptive design with cross sectional approach. The study was conducted at the Faculty of Nursing, University of Riau with a sample of 213 respondents by using proportionate stratified random sampling. The measuring instrument used is a questionnaire of academic stress and social support modified by the researcher with a validity range of 0.458-0.802 and 0.4610.574 . The analysis used univariate analysis and bivariate analysis. The results showed that majority of respondents were female, namely 200 (93.3\%), aged 20 years were 77 (36.2\%) and from batch A 2020 is 75 (35.2\%). The Majority of respondents who received high peer social support experienced heavy online learning academic stress levels as much as 35 (28.7\%) and moderate academic stress as many as 87 (71.3\%). Statistical test results obtained p value $=0.020<(0.05)$ meaning Ho is rejected The conclusion of the study is that There was a relationship between peer social support and academic stress of online learning during the COVID-19 pandemic.
\end{abstract}

Keywords: academic stress, online learning, peer social support 


\section{PENDAHULUAN}

Pembelajaran daring menjadi solusi perkuliahan yang diterapkan selama pandemi COVID-19 (Sadikin \& Hamidah, 2020). Proses pembelajaran daring membutuhkan penyesuaian tersendiri bagi mahasiswa. Penyesuaian ini dapat menimbulkan masalah, beban maupun kendala bagi mahasiswa. Kendala-kendala tersebut memicu terjadinya stres.

Stres yang sering dialami mahasiwa adalah stres akademik (Barseli, Ifdil, \& Nikmarijal, 2017). Penyebab stres akademik pembelajaran daring di kalangan mahasiswa seperti adanya kecemasan yang berlebihan dalam menghindari kegagalan, tugas yang diberikan lebih banyak daripada perkuliahan luring, koneksi jaringan internet yang tidak mendukung, materi perkuliahan yang sulit dimengerti, perkuliahan yang diganti dengan tugas serta dikumpulkan dalam waktu singkat secara daring dan terkurasnya tenaga pikiran karena tuntutan untuk selalu mengamati perkuliahan dari handphone atau laptop (Universitas Negeri Semarang, 2020).

Berdasarkan penelitian yang dilakukan oleh Firstika, Karim, dan Woferst (2020) didapatkan prevalensi tingkat stres akademik pada mahasiswa keperawatan A 2019 di Universitas Riau didapatkan 61 $(57,0 \%)$ mahasiswa yang mengalami stres berat sedangkan $46 \quad(43,0 \%)$ mahasiswa lainnya mengalami stres ringan. Sedangkan penelitian lain yang dilakukan oleh Lubis, Ramadhani, dan Rasyid (2021) pada 204 mahasiswa didapatkan hasil 14 orang $(6,9 \%)$ mengalami stres sangat tinggi, 55 orang (27\%) mengalami stres tinggi, 80 orang $(39,2 \%)$ mengalami stres sedang, 44 orang $(21,6 \%)$ mengalami stres rendah dan 11 orang $(5,4 \%)$ mengalami stres sangat rendah. Stres akademik tinggi dapat menurunkan kemampuan akademik individu yang berpengaruh pada indeks prestasi.

Stres akademik yang tidak dapat ditangani oleh mahasiswa akan mempengaruhi perasaan, fisik, pikiran, dan tingkah laku. Secara kognitif mahasiswa sulit berkonsentrasi, sulit mengingat dan mengerti materi pembelajaran serta selalu berpikir negatif terkait diri sendiri dan lingkungan.
Secara afektif timbulnya rasa cemas, menjadi lebih sensitif, marah, dan merasa putus asa (Aryani, 2016). Hal ini dapat berdampak pada munculnya gejala psikologis yang lebih serius seperti depresi serta dalam tingkat keparahan yang tinggi dapat sampai pada tindakan bunuh diri (Kholidah \& Alsa, 2012). Sedangkan secara fisiologis ditandai dengan jantung berdebar, muka memerah, pucat, badan lemah, badan terasa kaku, merasa tidak sehat, tramor, sakit perut, pusing, dan keringat dingin. Terakhir, secara tingkah laku timbulnya perilaku menghindar, malas mengikuti perkuliahan, membantah, menghina, perilaku merusak, menunda dalam menyelesaikan tugas perkuliahan serta terlibat dalam kegiatan yang tidak menguntungkan dan beresiko demi mencari kesenangan (Aryani, 2016). Perilaku negatif yang tidak menguntungkan tersebut seperti merokok, tawuran, seks bebas, alkoholik dan penyalahgunaan NAPZA (Suwartika, Nurdin, \& Ruhmadi, 2014). Untuk itu, perlunya upaya untuk mengurangi dampak stres akademik yang akan terjadi pada mahasiswa. Salah satu upaya yang dapat dijadikan solusi untuk mengurangi stres akademik yakni berupa dukungan sosial.

Dukungan sosial merupakan bentuk perhatian, kenyamanan, penghargaan maupun bantuan yang diterima individu dari individu lain atau kelompok (Sarafino \& Smith, 2011). Dukungan sosial virtual (online) adalah suatu hasil dari adanya komunikasi dan interaksi sosial melalui media online. Dukungan sosial tersebut diperoleh dari hubungan sosial yang akrab seperti orang tua, saudara, guru, dosen, lingkungan masyarakat dan teman sebaya (Tentama, 2014). Dukungan sosial teman virtual yaitu suatu bentuk dukungan yang memiliki arti tersendiri bagi penerima berupa bantuan tingkah laku, pemberian informasi, bantuan berupa materi dan emosional yang didapatkan dari interaksi sosial teman secara virtual melalui media sosial sebagai perantara dalam berkomunikasi antara satu dengan yang lain 
yang menjadikan penerima merasa diperhatikan, dicintai dan bernilai (Rachmawati \& Nurhamida, 2018).

Dukungan sosial teman sebaya secara virtual diberikan dengan bentuk dukungan emosional, dukungan penghargaan, dukungan informatif dan dukungan instrumental (Rachmawati \& Nurhamida, 2018). Dukungan ini akan menciptakan perasaan nyaman, merasa diperdulikan, dihormati, dan diberikan bantuan atau pertolongan bagi yang penerimanya (Sarafino \& Smith, 2011). Proses dukungan sosial sebagai proses komunikasi interaktif dalam jejaring sosial yang bermanfaat bagi kesejahteraan psikologis individu. Dukungan tersebut dapat mencegah dari ancaman kesehatan mental dan menjadikan individu lebih optimis dalam menjalani kehidupannya (Lestari, 2017). Dukungan sosial dapat mereduksi tingkat stres dan menggantikannya menjadi aspek-aspek positif (Prayudi, 2019).

Pada studi pendahuluan yang telah dilakukan peneliti tanggal 6 Maret 2021 pada 7 mahasiswa keperawatan angkatan 2018 dan 2017 Universitas Riau terkait tingkat stres akademik melalui WhatsApp didapatkan hasil 6 dari 7 mahasiswa mengatakan mengalami stres akibat tugas pembelajaran daring yang banyak, jaringan internet yang tidak strabil, tidak paham dengan penjelasan materi serta merasa bosan dan lelah melihat handphone atau laptop selama proses pembelajaran daring. Stres tersebut menimbulkan gejala stres seperti sakit kepala, sulit berkonsentrasi, gangguan tidur, cemas, merasa tegang, merasa bosan, lelah, takut gagal dan mendapatkan nilai rendah jika penyebab stres tidak bisa segera diatasi. Sedangkan 3 dari 6 mahasiswa yang mengalami stres akademik tersebut mengatakan kurang mendapatkan dukungan emosional dari teman selama melaksanakan perkuliahan daring, sementara 2 mahasiswa lainya mengatakan kurang mendapatkan dukungan penghargaan seperti ucapan terimakasih ketika sudah menyatukan tugas makalah kelompok Mahasiswa menyebutkan kurangnya mendapatkan dukungan tersebut dikarenakan kurangnya respek sesama teman karena terhalang jarak dan keterbatasan jaringan padahal dukungan tersebut sangat dibutuhkan dalam pelaksanaan pembelajaran daring.

Penelitian ini bertujuan untuk melihat untuk hubungan antara dukungan sosial teman sebaya dengan stres akademik pembelajaran daring. Berdasarkan uraian diatas, peneliti tertarik untuk melakukan penelitian mengenai hubungan antara dukungan sosial teman sebaya dengan stres akademik pembelajaran daring pada masa pandemi COVID-19.

\section{METODE PENELITIAN}

Jenis desain penelitian yang digunakan adalah deskriptif korelasi dengan teknik pendekatan cross sectional. Desain penelitian ini digunakan untuk mengetahui hubungan antara variabel dukungan sosial teman sebaya (independent variable) dengan stres akademik pembelajaran daring (dependent variable) pada masa pandemi COVID-19.

Pengambilan sampel dilakukan dengan menggunakan teknik probability sampling dengan jenis proportionate stratified random sampling. Perhitungan sampel pada penelitian ini berjumlah 213 responden dimana 69 responden dari angkatan 2018, 69 dari angkatan 2019 dan 75 responden dari angkatan 2020 dengan kriteria inklusi yakni terdaftar aktif secara akademik, bersedia menjadi responden dan belum bekerja.

Instrumen penelitian yang digunakan dalam penelitian ini yaitu kuesioner online dalam bentuk google form yang terdiri dari 3 jenis kuesioner yakni kuesioner A katakteristik responden, kuesioner B tentang stres akademik pembelajaran daring yang dikembangkan oleh Lin dan Chen (2009) dan telah dimodifikasi oleh peneliti dengan jumlah penyataan valid yaitu 21 pernyataan dengan nilai rentang validitas $0,458-0,802$ serta nilai uji reablitas croncach alpha yakni 0.904 dan 0,461-0,574dan kuesioner $\mathrm{C}$ tentang dukungan sosial teman sebaya mengacu 
pada bentuk dukungan sosial teman sebaya dari Sarafino dan Smith (2011) dengan jumlah pernyataan valid yakni 9 pernyataan dengan rentang nilai validitas 0,461-0,574 dan nilai uji reabilitas croncach alpha 0,800 .

Analisis data hasil penelitian menggunakan teknik analisis data univariat dan analisis data bivariat. Analisis data univariat disajikan dalam bentuk persentase dan tabel distribusi frekuensi yang bertujuan untuk melihat gambaran karakteristik responden berupa umur, jenis kelamin, program atau angkatan, melihat gambaran variabel independent yaitu dukungan sosial teman sebaya dan variabel depfendent yaitu stres akademik pembelajaran daring. analisis bivariat dalam penelitian ini bertujuan untul melihat hubungan antar variabel dengan menggunakan uji chi square. Penelitian ini sudah mendapatkan ethical clearance dari Komisi Etik Penelitian Keperawatan dan Kesehatan Fakultas Keperawatan Universitas Riau dengan nomor surat 181/ UN.19.5.1.8/KEPK.FKp/2021.

\section{HASIL}

Berdasarkan hasil penelitian yang telah dilakukan, maka diperoleh hasil sebagai berikut:

\section{Tabel 1. Distribusi Frekuensi Karakteristik Responden}

No. Katakteristik Jumlah Persentase (\%)

\begin{tabular}{|c|c|c|c|}
\hline 1. & $\begin{array}{l}\text { Jenis kelamin } \\
\text { - Laki-laki } \\
\text { - Perempuan }\end{array}$ & $\begin{array}{c}13 \\
200\end{array}$ & $\begin{array}{c}6,1 \\
93,9\end{array}$ \\
\hline & Total & 213 & 100 \\
\hline 2. & $\begin{array}{l}\text { Usia } \\
\text { - } 18 \text { tahun } \\
\text { - } 19 \text { tahun } \\
\text { - } 20 \text { tahun } \\
\text { - } 21 \text { tahun } \\
\end{array}$ & $\begin{array}{c}20 \\
72 \\
77 \\
41 \\
3 \\
\end{array}$ & $\begin{array}{c}9,4 \\
33,8 \\
36,2 \\
19,2 \\
1,4 \\
100\end{array}$ \\
\hline & Total & 213 & 100 \\
\hline 3. & $\begin{array}{l}\text { Angkatan } \\
\text { - A } 2020 \\
\text { - A } 2019 \\
\text { - A } 2018\end{array}$ & $\begin{array}{l}75 \\
69 \\
69\end{array}$ & $\begin{array}{l}35,2 \\
32,4 \\
32,4\end{array}$ \\
\hline & Total & 213 & 100 \\
\hline
\end{tabular}

Berdasarkan tabel 1 dapat dilihat dari 213 orang responden yang diteliti, distribusi responden menurut jenis kelamin diperoleh mayoritas responden berjenis kelamin perempuan, yaitu berjumlah 200 orang, usia diperoleh mayoritas umur 20 tahun, yaitu berjumlah 77 orang $(36,2 \%)$ dan berdasarkan angkatan mayoritas responden adalah angkatan A 2020 dengan jumlah responden yaitu 75 orang $(35,2 \%)$.

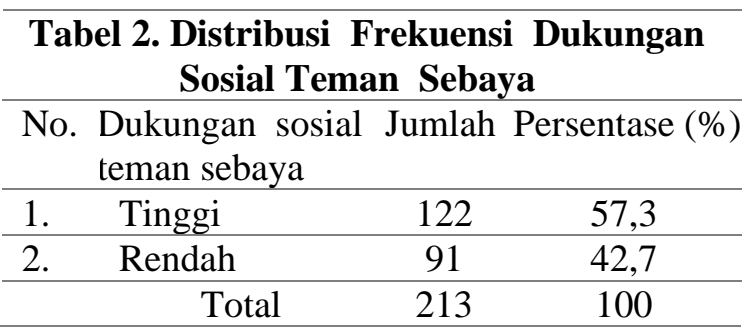

Berdasarkan tabel 2 diatas, diperoleh hasil mayoritas responden mendapat dukungan sosial teman sebaya yang tinggi, yaitu sebanyak 122 orang $(57,3 \%)$.

\section{Tabel 3. Distribusi Frekuensi Stres Akademik Pembelajaran Daring}

No. Stres Akademik Jumlah Persentase (\%) Pembelajaran daring

\begin{tabular}{llcc} 
1. & Berat & 76 & 35,7 \\
\hline 2. & Sedang & 137 & 64,3 \\
\hline 3. & Ringan & 0 & 0 \\
\hline & Total & 213 & 100 \\
\hline
\end{tabular}

Berdasarkan tabel 3 diperoleh hasil penelitian mayoritas responden mengalami stres akademik sedang, yaitu sebanyak 137 orang (69\%).

Tabel 4. Hubungan antara Dukungan Sosial Teman Sebaya dengan Stres Akademik Pembelajaran Daring pada Masa Pandemi COVID-19

\begin{tabular}{|c|c|c|c|c|c|c|}
\hline \multirow{3}{*}{$\begin{array}{l}\text { No. Dukungan } \\
\text { Sosial } \\
\text { Teman } \\
\text { Sebaya }\end{array}$} & \multicolumn{5}{|c|}{$\begin{array}{c}\text { Stres Akademik } \\
\text { Pembelajaran Daring }\end{array}$} & \multirow{3}{*}{$\begin{array}{c}\mathrm{P} \\
\text { value }\end{array}$} \\
\hline & \multicolumn{2}{|c|}{ Sedang } & \multicolumn{2}{|c|}{ Berat } & \multirow[t]{2}{*}{$\Sigma$} & \\
\hline & $\mathrm{N}$ & $\%$ & $\mathrm{~N}$ & $\%$ & & \\
\hline 1. Tinggi & 87 & 71,3 & 35 & 28,7 & 122 & \\
\hline 2. Rendah & 50 & 54,9 & 41 & 45,1 & 91 & 0,02 \\
\hline Total & 137 & 64,3 & 76 & 35,7 & 213 & 0 \\
\hline
\end{tabular}


Berdasarkan tabel 4, diketahui bahwa mayoritas responden mendapatkan dukungan sosial teman sebaya yang tinggi yaitu berjumlah 122 orang, dimana 87 orang $(71,3 \%)$ mengalami stres akademik pembelajaran daring sedang dan 35 orang $(28,7 \%)$ lainnya mengalami stres akademik pembelajaran daring berat. Responden yang mendapatkan dukungan sosial teman sebaya yang rendah berjumlah 91 orang, dengan responden yang mengalami stres akademik pembelajaran daring sedang berjumlah 50 orang $(54,9 \%)$ dan stres akademik pembelajaran daring berat sebanyak 41 orang $(45,1 \%)$. Adapun hasil uji statistik dengan analisa chi square didapatkan $\mathrm{p}$ value $0,020<\alpha 0,05$ yang artinya Ho ditolak.

\section{PEMBAHASAN}

\section{Karakteristik responden berdasarkan jenis kelamin}

Berdasarkan hasil penelitian yang telah dilakukan pada mahasiswa Fakultas Keperawatan Universitas Riau didapatkan dari 213, mayoritas responden berjenis kelamin perempuan, yaitu berjumlah 200 orang $(93,9 \%)$, hal ini dikarenakan pada Fakultas Keperawatan Universitas Riau lebih didominasi oleh perempuan dibandingkan laki-laki. Hasil penelitian ini sejalan dengan penelitian Lubis et al. (2021) tentang stres akademik mahasiswa dalam melakukan kuliah daring selama masa pandemi COVID-19 diperoleh hasil jenis kelamin yang mayoritasnya adalah perempuan dengan jumlah 123 orang $(60,3 \%)$. Selain itu, didukung pula hasil penelitian Andiarna dan Kusumawati (2020) yang mendapatkan hasil bahwa jenis kelamin perempuan sebanyak 228 orang $(80 \%)$ dan perempuan $(96 \%)$ mengalami tingkat stres lebih tinggi dibandingkan laki laki $(93 \%)$.

Variabel jenis kelamin memberikan sumbangan $1,9 \%$ terhadap stres akademik (Maryama, 2015). Mahasiswa berjenis kelamin perempuan mengalami stres berat sebanyak 2,7 kali lebih besar dibandingkan laki-laki (Sutjiato, Kandou, \& Tucunan, 2015). Perempuan lebih mudah cemas, mengalami perasaan bersalah jika mengalami tekanan dan lebih sensitif dibandingkan laki-laki sehingga perempuan lebih rentan terhadap kondisi stres (Kountul, Kolibu, \& Korompis, 2018).

\section{Karakteristik responden berdasarkan usia}

Hasil penelitian karakteristik responden berdasarkan usia diperoleh mayoritas umur 20 tahun, yaitu berjumlah 77 orang $(36,2 \%)$. Hasil penelitian ini sejalan dengan penelitian Lubis et al. (2021) yang mengatakan bahwa mahasiswa yang terlibat dalam penelitian mengalami stres akademik ketika melaksanakan kuliah daring dimayoritasi oleh usia 20 tahun yaitu berjumlah 87 orang $(42,6 \%)$. Penelitian Demolingo (2018) juga didapatkan responden yang paling banyak berumur 20 tahun yaitu berjumlah 42 orang $(57,5 \%)$.

Umur 20 tahun merupakan tahapan perkembangan remaja akhir (Sarwono, 2011). Pada usia remaja akhir perkembangan kognitif yang terjadi seperti kebingungan antara ideal dan kondisi nyata, dimana remaja dituntut beradaptasi untuk mengatasi perubahan dan masalah yang terus terjadi. Tuntutan untuk selalu berperilaku adaptif tersebut dapat menimbulkan stres (Lubis et al., 2021).

\section{Karakteristik responden berdasarkan angkatan}

Karakteristik responden berdasarkan angkatan dari angkatan A 2020 sampai angkatan A 2018 terdapat 213 responden yang diteliti mayoritas adalah angkatan A 2020 dengan jumlah responden yaitu 75 orang $(35,2 \%)$. Hal ini dikarenakan angkatan A 2020 merupakan angkatan dengan jumlah mahasiswa terbanyak daripada angkatan yang menjadi populasi pada penelitian ini. Stres yang terjadi pada individu tidak memandang umur, pekerjaan ataupun latar belakang (Firstika et al., 2020). Kerentanan terpaparnya stres terjadi pada usia generasi millenial khususnya pada mahasiswa tahun pertama (Setiawati, Wulandari, \& Mayestika, 2016). 


\section{Gambaran dukungan sosial teman sebaya} Hasil penelitian yang telah dilakukan, diperoleh hasil mayoritas responden mendapat dukungan sosial teman sebaya yang tinggi, yaitu sebanyak 122 orang $(57,3 \%)$. Asumsi peneliti, dukungan sosial teman sebaya yang tinggi disebabkan adanya hubungan sosial yang akrab, perasaan saling mengerti dan rasa kebersamaan yang tinggi sesama teman sebaya untuk menyelesaikan permasalahan yang dihadapi selama pembelajaran daring sehingga berdampak pada penyelesaian masalah, terbangunnya kepercayaan diri bagi individu, dan dapat memperbaiki prestasi akademik.

Dalam penelitian ini bentuk dukungan emosional yang diberikan berupa adannya kepedulian, menyemangati satu sama lain serta mendengarkan cerita secara virtual terkait kendala yang dihadapi ketika perkuliahan daring, dukungan instrumental berupa pengiriman bahan penunjang pembelajaran, dukungan penghargaan berupa pemberian apresiasi dan dukungan informasi berupa penyampaian informasi dan penjelasan terkait pembelajaran daring. Penelitian ini sejalan dengan penelitian Rohmah (2017) didapatkan hasil 166 orang $(51,875 \%)$ mendapatkan dukungan sosial teman sebaya tinggi. Dukungan sosial yang tinggi dapat merubah reaksi individu terhadap sumber stres. Individu yang memperoleh dukungan sosial yang tinggi akan merasakan dampak stres yang lebih minimal karena adanya bantuan dari orang lain (Christianto \& Adhiatma, 2019). Selain itu, dukungan sosial juga mampu melindungi individu dari efek negatif yang ditimbulkan akibat stres yang tinggi dan mempengaruhi kesehatan (Sarafino \& Smith, 2011).

\section{Gambaran stres akademik pembelajaran daring}

Hasil penelitian yang telah dilakukan di Fakultas Keperawatan Universitas Riau pada angkatan A 2020, A 2019 dan A 2018 didapatkan hasil bahwa mayoritas responden mengalami stres akademik sedang, yaitu sebanyak 147 orang (69\%). Penyebab stres akademik pada mahasiswa Fakultas
Keperawatan Universitas Riau dikarenakan adanya tekanan saat menghadapi ujian, tekanan dari dosen seperti tidak dapat menyesuaikan dengan metode pembelajaran yang dilaksanakan ketika daring, tekanan akan hasil akademik yang didapatkan tidak sesuai harapan, tekanan belajar dalam kelompok, tekanan teman sebaya seperti adanya persaingan, tekanan yang diakibatkan diri sendiri karena adanya persepsi individu terhadap ketidakyakinan akan kemampuannya, dan tekanan terkait kemampuan dalam managemen waktu. Tuntutan untuk memahami dan menguasai pengetahuan, materi, dan keterampilan dalam waktu yang singkat dapat menyebabkan stres bagi mahasiswa (Oktaria, Sari, \& Azmy, 2019).

Sejalan dengan penelitian yang dilakukan oleh Inama (2021) diperoleh hasil mayoritas responden mengalami stres akademik sedang, yaitu sebanyak 54 orang $(49,1 \%)$. Didukung penelitian Sari (2020) didapatkan 27 mahasiswa $(38,57 \%)$ mengalami stres sedang, dimana stressor yang dialami mahasiswa ketika wabah COVID-19 ini berlangsung yaitu adanya kekhawatiran saat pergi keluar rumah, ketakutan tertular COVID-19, sulit mengerti materi saat perkuliahan daring, dan kebosanan saat melakukan social distancing. proses perkuliahan dari rumah, dengan dibantu adanya dukungan emosional dan supervisi yang optimal secara tidak langsung dapat mempengaruhi penurunan tingkat stres mahasiswa (Kumari et al., 2020). Tingkat stres akademik pembelajaran daring yang sedang menunjukkan adanya penyesuaian dan adaptasi yang cukup baik dalam mengikuti pembelajaran daring.

\section{Hubungan antara dukungan sosial teman sebaya dengan stres akademik pembelajaran daring}

Hasil penelitian analisa bivariat dalam penelitian ini bertujuan untuk menilai hubungan antara dukungan sosial teman sebaya dengan stres akademik 
pembelajaran daring pada masa pandemi COVID-19 bagi mahasiswa Fakultas Keperawatan Universitas Riau dengan menggunakan uji chi square didapatkan $\mathrm{p}$ value $0,020<\alpha 0,05$ yang artinya Ho ditolak sehingga dapat disimpulkan bahwa ada hubungan antara dukungan sosial teman sebaya dengan stres akademik pembelajaran daring pada masa pandemi COVID-19.

Hasil penelitian ini didapatkan bahwa mayoritas responden mendapatkan dukungan sosial teman sebaya yang tinggi yaitu sebanyak 122 orang, dimana 87 orang $(71,3 \%)$ mengalami stres akademik pembelajaran daring sedang dan 35 orang $(28,7 \%)$ lainnya mengalami stres akademik pembelajaran daring berat. Hal ini menunjukkan bahwa mayoritas responden mendapatkan dukungan sosial teman sebaya tinggi dengan tingkat stres akademik pembelajaran daring sedang. Peneliti berasumsi, stres akademik pembelajaran daring sedang disebabkan adanya dukungan sosial dari teman sebaya secara virtual baik berupa dukungan penghargaan, dukungan informasi, dukungan instrumen dan dukungan emosional yang mempengaruhi tingkat stres akademik pembelajaran daring yang dirasakan mahasiswa. Penelitian Besser dan Zeigler-hill (2014) menyebutkan bahwa pengurangan tingkat kecemasan dan stres yang tinggi dapat dilakukan dengan adanya dukungan sosial. Dukungan sosial mampu meningkatkan kemampuan individu dalam menghadapi atau memecahkan suatu masalah yang berfokus pada pengurangan reaksi stres melalui kepedulian, perhatian, adanya informasi serta respon balik yang dibutuhkan untuk memperoleh koping stres yang baik (Santoso, 2020).

Tingkat stres akademik pembelajaran daring sedang juga disebabkan adanya penyesuaian terhadap sistem pembelajaran daring dimana pelaksanaan pembelajaran daring yang dilaksanakan dalam rentang waktu yang cukup lama yaitu mencapai 1 tahun lamanya sehingga kondisi ini menyebabkan mahasiswa menganggap permasalahan dan tekanan yang dihadapi ketika daring bukan merupakan suatu masalah besar yang tidak bisa diatasi. Perbedaan hasil penelitian yang didapatkan dengan studi pendahuluan, dimana hasil penelitian mendapatkan bahwa mayoritas mahasiswa mendapatkan dukungan sosial teman sebaya tinggi dengan stres akademik sedang, sedangkan pada studi pendahuluan yang telah dilakukan pada awal penelitian dimana didapatkan bahwa mahasiswa kurang mendapat dukungan sosial teman sebaya sehingga mengalami stres akademik pembelajaran daring.

Perbedaan ini disebabkan pada studi pendahuluan pelaksanaan pembelajaran daring baru diterapkan sehingga mahasiswa belum dapat menyesuaikan dan adaptasi terhadap tekanan akademik pembelajaran daring. Tekanan akademik penyebab stres mahasiswa selama pandemi COVID-19 seperti tidak dapat mengikuti pembelajaran daring karena kuota internet yang terbatas $(37,4 \%)$, tugas pembelajaran $(70 \%)$, bosan dirumah $(57,8 \%)$, tidak dapat bertemu dengan orang-orang yang disayangi $(40,2 \%)$, proses pembelajaran daring yang membosankan (55,8\%), tidak dapat melaksanakan hobi seperti biasanya $(35,8 \%)$ dan tidak dapat mengaplikasikan pelajaran praktek laboratorium karena ketidaksediaan alat $(35 \%)$ (Livana, Mubin, \& Basthomi, 2020). Selain itu, kondisi pandemi yang memaksa mahasiswa untuk belajar dan tetap berada dirumah, membuat interaksi dan intensitas komunikasi dengan teman sebaya menjadi berkurang. Minimalnya komunikasi dan interaksi sosial yang dilakukan mahasiswa selama perkuliahan daring dapat mempengaruhi tingginya stres akademik yang dialami mahasiswa (Lubis et al., 2021). Penelitian Thawabieh dan Qaisy (2012) menyebutkan bahwa mahasiswa yang mengalami masalah dalam komunikasi sosialnya menyebabkan tingkat stres menjadi tinggi.

Tingginya tingkat stres akademik yang dialami mahasiswa dapat diturunkan dengan dukungan sosial teman sebaya yang tinggi (Salam, Suharnan, \& Matulessy, 2019). Mengingat teman sebaya menduduki peran penting dalam pengambilan 
\begin{tabular}{lccr}
\multicolumn{2}{c}{ keputusan termasuk } & alternatif \\
pemecahan masalah. & Hal & tersebut \\
dikarenakan & teman & sebaya & dirasa
\end{tabular} mempunyai pemikiran yang sama serta dapat diajak bertukar pikiran untuk mencari alternatif pemecahan masalah (Sarafino \& Smith, 2011). Penelitian ini sejalan dengan penelitian Faqih (2020) yang menyebutkan bahwa ada pengaruh dukungan sosial teman sebaya terhadap stres akademik mahasiswa Malang yang bekerja. Penelitian lain yang dilakukan oleh Firdiansyah (2020), Jannah (2020) dan Salmon dan Santi (2021) menerangkan bahwa ada hubungan negatif yang sangat signifikan antara dukungan sosial teman sebaya dengan stres akademik mahasiswa. Apabila dukungan sosial teman sebaya positif maka stres akademik mahasiswa rendah, namun apabila dukungan sosial teman sebaya negatif maka stres akademik mahasiswa tinggi. Tingkat dukungan sosial yang tinggi juga dapat mempengaruhi kesehatan dan kesejahteraan psikologis yang lebih baik dibandingkan individu dengan dukungan sosial rendah (Szkody, Stearns, Stanhope, \& Mckinnney, 2020).

\section{KESIMPULAN}

Berdasarkan hasil penelitian yang dilakukan tentang hubungan antara dukungan sosial teman sebaya dengan stres akademik pembelajaran daring pada masa pandemi COVID-19, dapat disimpulkan bahwa hasil penelitian analisis univariat didapatkan bahwa karakteristik responden berdasarkan jenis kelamin mayoritas adalah berjenis kelamin perempuan yaitu sebanyak 200 orang $(93,9 \%)$, berdasarkan usia didominasi oleh responden berusia 20 tahun yaitu berjumlah 77 orang $(36,2 \%)$ dan berdasarkan angkatan sebagian besar yaitu angkatan A 2020 yaitu sebanyak 75 orang $(35,2 \%)$. Mayoritas responden mendapatkan dukungan sosial teman sebaya tinggi yaitu berjumlah 122 orang $(57,3 \%)$ dan sebagian besar mengalami stres akademik pembelajaran daring sedang yaitu sebanyak 137 orang $(64,3 \%)$. Berdasarkan hasil analisis bivariat pada penelitian yang telah dilakukan didapatkan bahwa p value $0,020<$ $\alpha$ 0,05 yang artinya Ho ditolak sehingga dapat disimpulkan ada hubungan antara dukungan sosial teman sebaya dengan stres akademik pembelajaran daring pada masa pandemi COVID-19.

Hasil penelitian ini diharapkan dapat dijadikan sebagai data dasar, rujukan dan sumber pengetahuan akan pentingnya dukungan sosial sesama teman sebaya untuk mengurangi dan mengatasi stres akademik pembelajaran daring yang dialami oleh mahasiswa.

\section{UCAPAN TERIMAKASIH}

Penulis mengucapkan terimakasih untuk semua pihak yang telah membantu peneliti dalam membuat skripsi penelitian ini.

\section{DAFTAR PUSTAKA}

Aryani, F. (2016). Stres belajar. Makassar: Edukasi Mitra Grafika.

Barseli, M., Ifdil, I., \& Nikmarijal, N. (2017).

Konsep Stres Akademik Siswa. Jurnal

Konseling Dan Pendidikan, 5(2005), 143-148.

Besser, A., \& Zeigler-hill, V. (2014). Self and Identity: Positive Personality Features and Stress among First-year University Students: Implications for Psychological Distress , Functional Impairment , and Self- esteem. https://doi.org/10.1080/15298868.2012 .736690

Christianto, L. P \& Adhiatma, W. (2019). Suara psikologi: untuk insan Indonesia. Jakarta: Unika Atma Jaya.

Faqih, M. F. (2020). Pengaruh Dukungan Sosial Teman Sebaya terhadap Stres Akademik Mahasiswa Malang yang Bekerja. UIN Maulana Ibrahim Malang.

Firdiansyah, M. R. (2020). Hubungan Antara Dukungan dengan Stress Akademik Mahasiswa Universitas Muhammadiyah Surakarta.

Firstika, Z., Karim, D., \& Woferst, R. (2020). Hubungan Tingkat Stres Akademik dengan Sistem Perkuliahan Jarak Jauh Berbasis Online terhadap Kualitas Tidur Mhasiswa Tahun 
Pertama. Jurnal Online Mahasiswa FKp, $7(2), 45-52$.

Inama, S. (2021). Gambaran Tingkat Stres Mahasiswa Fakultas Kedukteran Universitas Sumatera Utara dalam Sistem Pembelajaran Daring pada Era Pandemi COVID-19. Universitas Sumatera Utara.

Jannah, S. M. (2020). Hubungan anatara Dukungan Sosial dengan Stres Akademik pada Mahasiswa yang Menjalani Pembelajaran Jarak Jauh Akibat covid-19. Universitas Diponegoro.

Kholidah, E. N., \& Alsa, A. (2012). Berpikir Positif Menurunkan Stres Psikologis. Jurnal Psikologi, 39(1), 67-75.

Kountul, Y. P. D., Kolibu, F. K., \& Korompis, G. E. C. (2018). Hubungan Jenis Kelamin dan Pengaruh Teman Sebaya dengan Tingkat Stres Mahasiswa Fakultas Kesehatan Masyarakat Universitas Sam Ratulangi Manado. Jurnal KESMAS, 7(5).

Kumari, A., Singh, S. B., Mahajan, S., Sharma, V., Ranjan, R., Vohra, P., \& Al, E. (2020). Stress Assessment in Mbbs First Year Students Before and After Stress Management Training During Covid-19 Lockdown: a North Indian Study'. International Journal of Medical and Biomedical Studies, 4(9), 33-38.

Lestari, S. (2017). Hubungan Dukungan Sosial dengan Tingkat Stres pada Mahasiswa Program Studi D IV Bidan Pendidik Universitas Aisyiyah Yogyakarta. Universitas Aisyiyah Yogyakarta.

Lin, Y. M., \& Chen, F. S. (2009). Academic stress inventory of students at universities and colleges of technology. World Transactions on Engineering and Technology Education, 7(2), 157162.

Livana, P., Mubin, M. F., \& Basthomi, Y. (2020). “ tugas pembelajaran " penyebab stres mahasiswa selama pandemi covid-19. Jurnal Ilmu Keperawatan Jiwa, 3(2), 203-208.

Lubis, H., Ramadhani, A., \& Rasyid, M.
(2021). Stres Akademik Mahasiswa dalam Melaksanakan Kuliah Daring Selama Masa Pandemi Covid 19. 10(1), 31-39.

https://doi.org/10.30872/psikostudia

Oktaria, D., Sari, M. I., \& Azmy, N. A. (2019). Perbedaan Tingkat Stres pada Mahasiswa Tahap Profesi yang Menjalani Stase Minor dengan Tugas Tambahan Jaga dan Tidak Jaga di Fakultas Kedokteran Universitas Lampung. JK Unila, 3(1), 112-116.

Prayudi, A. N. H. (2019). Hubungan antara Dukungan Sosial dengan Stres pada Pecandu Narkoba yang sedang Berada dalam Masa Rehabilitasi di Kota Semarang. Universitas Negeri Semarang.

Rachmawati, A., \& Nurhamida, Y. (2018). Dukungan Sosial Teman Virtual Melalui Media Instagram pada Remaja Akhir. Jurnal Ilmiah Psikologi Terapan, 06(01).

Rohmah, Q. (2017). Pengaruh Dukungan Sosial Teman Sebaya Terhadap Stres pada Mahasiswa yang Mengerjakan Skripsi di Universitas Muhammadiyah Malang. Universitas Muhammadiyah Malang.

Sadikin, A., \& Hamidah, A. (2020). Pembelajaran Daring di Tengah Wabah Covid-19 ( Online Learning in the Middle of the Covid-19 Pandemic ). BIODIK: Jurnal Ilmiah Pendidikan Biologi, 6(1), 214-224.

Salam, A., Suharnan, \& Matulessy, A. (2019). Hubungan Antara Efikasi Diri dan Dukungan Sosial dengan Stres Akademik Pada Siswa. Jurnal Bimbingan Konseling Islam, 1, 325342.

Salmon, A. G., \& Santi, D. E. (2021). Dukungan Sosial dengan Stres Akademik Mahasiswa Perantau dalam Pembelajaran Daring di Masa Pandemi. (April), 128-135.

Santoso, M. D. Y. (2020). Review Article: Dukungan Sosial dalam Situasi Pandemi COVID-19. In Press Jurnal Litbang Sukowati, 5(1), 11-26. 
https://doi.org/10.32630/sukowati.v5i1.184

Sarafino, E. P., \& Smith, T. W. (2011). Health Psychology: Biopsychosocial Interactions (7th ed.). New York: John Willey \& Sons.

Sari, M. K. (2020). Tingkat Stres Mahasiswa S1 Keperawatan Tingkat Satu dalam Menghadapi Wabah COVID-19 dan Perkuliahan Daring di Stikes Karya Husada Kediri. 31-35.

Sarwono. (2011). Psikologi Remaja Edisi Revisi. Jakarta: Rajawali Press.

Semarang, U. N. (2020). Edisi COVID-19: Disertasi Hasil Survei Aktifitas Mahasiswa Jurusan IKM Selama WFH. Semarang.

Setiawati, O. R., Wulandari, M., \& Mayestika, D. (2016). Hubungan Kualitas Tidur dengan Stres pada Mahasiswa Fakultas Kedokteran Universitas Malahayati Tahun Akademik 2015/2016. 26.

Sutjiato, M., Kandou, G. ., \& Tucunan, A. A. . (2015). Hubungan Faktor Internal dan Eksternal dengan Tingkat Stres pada Mahasiswa Fakultas Kedokteran Universitas Sam Ratulangi Manado. JIKMU, 5(1).

Suwartika, I., Nurdin, A., \& Ruhmadi, E. (2014). Analisis Faktor yang Berhubungan dengan Tingkat Stres Akademik Mahasiswa Reguler Program Studi DIII Keperawatan Cirebon Poltekkes Kemenkes Tasikmalaya. Jurnal Keperawatan Soedirman, 9(3), 173-189.

Szkody, E., Stearns, M., Stanhope, L., \& Mckinnney, C. (2020). Stress-Buffering Role of Social Support During COVID19. Family Process, 1-4.

Tentama, F. (2014). Dukungan Sosial dan Post-Traumatic Stress Disorder. Jurnal Psikologi Undip, 13(2), 133-138.

Thawabieh, A. M., \& Qaisy, L. M. (2012). Assessing Stress Among University Student. American International Journal of Contemporary Research. 